\title{
Some Doctrinal Aspects Contained into the Religious Questions of Ibn Khatima's Treatise of the Pest (14th Century)
}

\author{
Luisa María Arvide Cambra
}

Department of Philology, University of Almeria, Spain

Copyright $(2017$ by authors, all rights reserved. Authors agree that this article remains permanently open access under the terms of the Creative Commons Attribution License 4.0 International License

\begin{abstract}
This paper is a study of fragments contained into the religious questions (VII-X) of pest treatise, entitled in Arabic "Tahsil gharad al-qasid fi-tafsil al-marad al-wafid" (succeeding in clarify pest disease), which was written in the $14^{\text {th }}$ century by the well-known Spanish physician Ibn Khatima (d.circa1369), being referred to the Black Death, the terrible pandemic that devastated Asia, Africa and Europe at that time. The article includes an introduction about the author and his literary and scientific significance, as well as a section containing a few fragments of the religious questions (VII-X), translated to English from the Arabic manuscript no.1785 from the Library of El Escorial and concerning to some doctrinal aspects of the Hadith, the dogmatic law of Medieval Islam and the Islamic thought in the Middle Ages.
\end{abstract}

Keywords Ibn Khatima, The Black Death, Epidemics and Plagues, Hadith Literature, Andalusian Islamic Thought, Medieval Islamic Religious Literature

\section{Introduction}

Abu Dja'far Ahmad ibn Ali ibn Muhammad ibn Ali ibn Khatima Al-Ansari (c.1324-c.1369), known as Ibn Khatima, is one of the most important intellectuals of the Medieval Moorish Spain [1]. He wrote works in different fields, such as literature (poetry), history and medicine [2], and his major work in medicine is titled "Tahsil gharad al-qasid fi-tafsil al-marad al-wafid" (succeeding in clarify pest disease) [3] and is collected in three Arabic manuscripts: a) no.1785from the Library of El Escorial in Spain, the most complete of them all; b) no.6369 from Deutsche Staatsbibliothek zu Berlin, in Germany, which is very close to El Escorial manuscript but more fragmented than it; and c) no.CCLXVIII from National Library of Madrid, in Spain, which is a literal copy of El Escorial manuscript [4].
The work is divided into ten questions or parts. The first six ones (Questions I-VI) are about medical topics: causes, symptoms and treatment to combat the plague [5]. The remaining four (Questions VII-X) [6], which are the subject of this article, are of religious nature and deal about what Islam says about the epidemics having in account the tradition of Hadiths [7][8] and the Islamic canon law [9][10], and taking into consideration the Muslim jurisprudence [11][12], and the Medieval Islamic thought [13].

In the questions I-VI, the book advises on how to be protected from the disease and how to prevent infection. It also indicates palliative therapy guidelines to patients, including recipes of high dietetic and pharmacological value [14]. In these pages Ibn Khatima anticipates the way to scientific discoveries of $19^{\text {th }}$ and $20^{\text {th }}$ centuries in relation to the disease transmission theory and the contagion as well as the need for isolation in case of infection [15], etc, and he approaches to the types of plagues that modern science establishes in diseases classification, i.e., bubonic pest, pneumonic pest and septicemic pest.

As I mentioned earlier, questions VI to X from this treatise include interesting points about Hadith literature, Medieval Islam dogmatic law, Medieval Muslim jurisprudence and Andalusian Islamic thought, as well as deal with several religious controversies that are caused by the social and human aspects from the plague disease and other pandemics.

The issues these ten questions precisely tackle are listed below:

- Question I: About plague nature.

- Question II: About both the general and specific causes of plague.

- $\quad$ Question III: About plague geographical factors.

- Question IV: About plague transmission and contagion.

- Question V: About how to protect oneself from plague and keep away.

- Question VI: About plague treatment.

- Question VII: About what Islamic canon law indicates about plague and other epidemics. 
- $\quad$ Question VIII: About the meaning of Hadith "To refuse to enter a land attacked by plague or to get away.

- Question IX: About the meaning of the Prophet's saying "There is no contagious disease or evil omen".

- Question X: About how is the joining or the connection between both Hadiths.

The content of the religious questions, i.e., Questions VII-X, which this paper concerns, is mostly based on the Hadith. The Hadith is a genre of Arabic literature that refers to the sayings and deeds of God's Messenger, Muhammad, as the basis of the Sunna (tradition). The Hadith is after the Holy Book (The Qur'an) the second cornerstone of Sunni Islam. Every Hadith is started in a stereotyped way by using expressions such as 'I heard', 'I have been told', etc., to what it follows a chain of transmission or list of persons who have referred to the story from generation to generation, until reaching a disciple or companion of Prophet Muhammad. This transmission process shows its truthfulness. Among the most considered and prestigious collections of Hadiths are those of Al-Bukhari [16][17] and Muslim [18][19], both entitled Sahih, which are quoted by Ibn Khatima in this part of the Tahsil and are included in the translated fragments below.

In these pages of the work, Ibn Khatima gathers the ancient theories of the divine punishment considering catastrophes caused by the epidemics that humanity had historically been suffering as a way of atonement for sins committed. This theory of epidemics as a consequence of God's anger was directly or indirectly mentioned by Hippocrates too, according to what Ibn Khatima quotes on this matter.

The plague patient is considered as a martyr [20] in the Islam. In general terms, as Tahsil texts make it clear, Prophet Muhammad warned don't go to a land attacked by the plague in order to avoid contagion, but, if someone is caught inside an area affected by the epidemic, he should not leave running away from the disease, since this condition is caused by God's will and, therefore, we must accept the Divine Decree and withstand the misfortune as a testimony of martyrdom.

\section{Doctrinal Aspects of Medieval Islam on Epidemics and Plagues}

Some of the doctrinal aspects of Medieval Islam on epidemics and plagues contained in the Tahsil, according to the Arabic Manuscript no.1785 from El Escorial Library, are enclosed in the following fragments.

\subsection{Fragment from the Question VII (F.86v $)$}

In Al-Bukhari's Sahih, taking Yahyà ibnYa'mar [21] as source and this one from Aisha, the Prophet's wife, God bless and save Him!, we can read she informs him that she had asked God's Messenger, God bless and save Him!, about the plague; and He said to her that it was a punishment sent by God to whom He had wanted, and He had created it out of compassion and mercy of believers. Every servant of God staying in a land struck by plague knows that what afflicts him will be his reward to be a martyr. Furthermore, taking Anas ibn Malik [22] as source, we can read: God's Messenger, God bless and save Him! , said: "Plague is a testimony of faith and martyrdom to all Muslims".

\subsection{Fragment from the Question VIII (F.92 $\left.\mathbf{v}^{\circ}-93 r^{\circ}\right)$ (F.94v $\left.{ }^{\circ}\right)$}

Abu Ubayda ibn Al-Jarrah [23] added: Abd Al-Rahman ibn Awf [24], who had gone off due to a need, arrived and said: Certainly, I know about this. I heard God's Messenger say, God bless and save Him!: "If you hear [F.93r ${ }^{\circ}$ that an epidemic is plaguing some land, do not go over; but, if you are in a territory in which the epidemic has developed, do not run away from it" (...)

It has been known from Amr ibn Al-As [25] that he said: Plague is a punishment. Run away from it.

Sharhabil ibn Hasanà [(26] said: I heard God's Messenger say, God bless and save Him!: "Epidemics and plagues are the mercy of your Lord, the request of your Prophet and the death of the pious who preceded you. Do not run away from them".

\subsection{Fragment from the Question IX (F.95r $\left.{ }^{\circ}\right)$}

As for the Hadith "There is no contagion", in the Two Sahihs (Muslim's Sahih and Al-Bukhari's Sahih) [27] and Muslim's lafz, taking Ibn Shihab [28] as source, it is said that God's Messenger, God bless and save Him!, said: "There is no contagion". It is also said that God's Messenger, God bless and save Him, added!: "The patient will not be ever received by a healthy person".

\subsection{Fragment from the Question X (F. 99v $\left.-100 r^{\circ}\right)$}

Praise God who gives success! We say that the Hadith on the prohibition to enter a land attacked by plague or run away from it, does not come from any of our Imams. Related to this, we have received a saying with abrogation [29][30] whose meaning is fully resolved in Question VIII. Regarding the Hadith "There is no contagion", there are the controversies mentioned in the previous Question (Question IX), and it was already proved [F.100r $\left.\mathrm{r}^{\circ}\right]$ the weakness of this saying that has been abrogated by His saying, Peace be on Him: "The patient will not be ever received by a healthy person".

\section{Conclusions}

These pages exemplify Ibn Khatima relevance in history of both Arabic science and Islamic literature. His work Al-Tahsil is in a high-ranking place within medicine and 
pharmacology of Al-Andalus as well as Hadith literature and Medieval Islamic thinking on epidemics and plagues.

\section{REFERENCES}

[1] M.Ullmann. Die Medizinim Islam. E.J.Brill, Leiden/Köhl, 246-247, 1970.

[2] M.A.Al-Khattabi. Atteb wa al-atibba fi al-Andalus al-Islamia, Vol.2. Beyrouth, pp.151-161, 1988.

[3] M.Antuña.Abenjátima de Almería y su tratado de la peste.Religión y cultura, Vol. I, 68-90, 1928.

[4] L.M.Arvide Cambra. Prescripciones médicas de Ibn Jatima para el tratamiento paliativo en la enfermedad de la peste bubónica. European Scientific Journal, Vol.9, No 18, 13-19, 2013.

[5] L.M.Arvide Cambra. El tratado de la peste de IbnJatima (I). Cuestiones I-VI. Logos Verlag, Berlin, 2014.

[6] L.M.Arvide Cambra. El tratado de la peste de IbnJatima (II). Cuestiones VII-X. Logos Verlag, Berlin, 2017.

[7] A.Guillaume. The Traditions of Islam: An Introduction to the Study of the Hadith Literature. Oxford, 1924.

[8] M.H.Kamali. A Textbook of Hadith Studies. Authenticity, Compilation, Classification and Criticism of Hadith. Leicester, 2005.

[9] I.Goldziher. Le dogmeet la loi de l'Islam; histoire du développement dogmatique et juridique de la religion musulmane (French translation by Félix Arin). Paris, 1920.

[10] N.J.Coulson. A History of Islamic Law. Oxford, 1964.

[11] N.Calder. Norman. Studies in Early Muslim Jurisprudence. Oxford, 1993.

[12] M.H.Kamali. Principles of Islamic Jurisprudence. Cambridge, 2005.

[13] I.Goldziher. Introduction to Islamic Theology and Law. Princeton, New Jersey, 1981.

[14] L.M.Arvide Cambra. Some Pharmaceutical Recipes for the Treatment of the Bubonic Pest Contained into the Kitab Al-Tahsil of Ibn Khatima (D.1369).Advances in
Pharmacology and Pharmacy, Vol. 1, No.2, 85-87, 2013.doi: 10.13189/app.2013.010206.

[15] D.T.Dennis, P.S. Mead. Yersinia species, including plague. Principles and Practice of Infectious Diseases, Elsevier Churchill Livingstone, Philadelphia, chapter 229, 2009.

[16] J.Robson. Encyclopaedia of Islam, New Edition, Vol.II, pp. 1296-1297; sub voce Al-Bukhari.

[17] Ibn Khallikan. Wafayat al-a‘yan; ed. F.Wüstenfeld. Gottingae, 1835, p.541.

[18] G.H.A.Juynboll. Encyclopaedia of Islam, New Edition, Vol VII, pp.691-692; sub voce Muslim b. Al-Hadjdjadj.

[19] G.H.A.Juynboll. Muslim tradition. Studies in chronology, provenance and authorship of early hadith. Cambridge, 1983.

[20] J.Bowker. The Problem of Suffering in the Qur'an. Religious Studies, Vol. 4, No.2, 183-202, 1969.

[21] N.Calder \& J.Mojaddedi \& A.Rippin. Classical Islam: A Sourcebook of Religious Literature. London-New York, 2003, p.82.

[22] A.J. Wensinck \& J. Robson. Encyclopaedia of Islam, New Edition, VolI, p.482; sub voce Anas b. Malik.

[23] H.A.R.Gibb. Encyclopaedia of Islam, New Edition, Vol I, pp.158-159; sub voce Abu Ubayda Amir b. Abd Allah b. Al-Djarrah.

[24] M.Th.Houtsma \& W.M.Watt. Encyclopaedia of Islam, New Edition, Vol I, p.84; sub voce Abd Al-Rahman b.Awf.

[25] A.J.Wensinck. Encyclopaedia of Islam, New Edition, Vol I, p.451; sub voce Amrb. Al-As.

[26] IbnSa‘d. Kitab Al-Tabaqat Al-Kabir, Vol. IV, p.119.

[27] J.Browne. The Canonitation of Al-Bukhari and Muslim. The Formation and Function of the Sunni Hadith Canon. Leiden, 2007.

[28] M.Lecker. Biographical Notes on Ibn Shihab Al-Zuhri. Journal of Semitic Studies, Vol. XLI, No.1, 21-63, 1996.doi: 10.1093/jss/XLI.1.21.

[29] J.Burton. The Sources of Islamic Law: Islamic Theories of Abrogation. Edinburgh, 1990.

[30] L.Fatoohi. Abrogation in the Qur'an and Islamic Law. New York, 2012. 